6 Baron, J H, Gut, 1963, 4, 136.

7 Gray's Anatomy, ed D V Davies, 34th edn, p 74. London, Longmans, 1967.

${ }^{8}$ Spiro, H M, and Miles, S S, New England Medical fournal, 1970, 263, 286.

- Ventkateswaran, P S, Jeffers, A, and Hocken, A G, British Medical Fournal, 1972, 4, 22.

10 Shepherd, A M M, Stewart, W K, and Wormsley, K G, Lancet, 1973, 1 , 1357.

11 Fillastre, J P, et al, Revue Française d'Etudes Cliniques et Biologiques, 1965, 10,180
12'Dorph, S, et al, Scandinavian fournal of Gastroenterology, 1972, 7, 589.

13 Goldstein, H, et al, Archives of Internal Medicine, 1967, 120, 645.

14 Canavan, J S F, Briggs, J D, and Bell, P R F, British fournal of Surgery, $1975,62,737$.

15 McConnell, J B, et al, Lancet, 1975, 2, 1121

${ }^{16}$ Rabiner, S F, Medical Clinics of North America, 1972, 56, 221.

${ }_{17}^{17}$ Lewicki, A M, Saito, S, and Merrill, J P, Radiology, 1972, 102, 533.

18 Aubrey, D A, and Burns, G P, American fournal of Surgery, 1973, 125, 676.

\title{
Persistent measles infection in malnourished children
}

\author{
J DOSSETOR， H C WHITTLE， B M GREENWOOD
}

British Medical fournal, 1977, 1, 1633-1635

\section{Summary}

Thirty malnourished and 25 well-nourished children were studied six to 31 days after the onset of a measles rash. Evidence of the virus was found in $40 \%$ of the malnourished children but in none of the well-nourished controls. Giant cells were found in the nasal secretions of five out of 17 malnourished children and measles antigen was detected in the lymphocytes of eight out of 28 . The malnourished children showed depressed cell-mediated immunity to measles and candida antigens and a low response to meningococcal vaccine. Fifteen died from intercurrent infections. Malnutrition was thought to have depressed the immune response in these children, resulting in a severe and prolonged attack of measles. This, in turn, led to further damage to the immune system and more severe malnutrition. Thus these children were made susceptible to intercurrent infection.

\section{Introduction}

Measles in tropical countries is often severe, especially in children who develop a dark desquamating rash. ${ }^{1}$ Such children may lose much weight and take up to three months to regain it. Scheifele and Forbes in Kenya showed that these children continued to excrete giant cells for an average of 12 days after the appearance of the rash. ${ }^{2}$ On this evidence they suggested that measles infection persisted longer in malnourished children.

In Zaria, where this syndrome of severe measles is common, we looked for persisting measles virus in children who were malnourished after measles, because we thought that their disease might be due to persistence of the virus. We report here evidence that there is indeed persistent virus in malnourished children after measles.

\section{Patients and methods}

Thirty children who had had a measles rash for over one week and who were not recovering normally were studied. The mean duration

\footnotetext{
Departments of Paediatrics and Medicine, Ahmadu Bello University Hospital, Zaria, Nigeria

J DOSSETOR, MRCP, lecturer, (now lecturer in child health, Hospital for Sick Children, Glasgow G3 8SJ)

H C WHITTLE, MRCP, senior lecturer

B M GREENWOOD, MRCP, senior lecture
}

between the onset of the rash and the time of presentation was 13 days (range 6-31 days) and the mean age ( $\pm 1 S \mathrm{SD})$ of the children was $22 \pm 10$ months. All of these children were weak and anorectic and had diarrhoea; 13 had bronchopneumonia; six had oral candidiasis; and eight others had ulcerative stomatitis. Ten had had a severe rash, in which widespread skin desquamation had occurred. Eleven were underweight, 11 were marasmic, five had marasmic kwashiorkor, and three had kwashiorkor. ${ }^{3}$ The overall mortality in this group was $50 \%$ despite intensive treatment in hospital and nutritional advice to the mother on discharge.

Twenty-five well-nourished children who had recovered normally from measles were also studied as controls. Their mean age was $19 \pm 13$ months and they had had measles on average 12 days earlier (range 7-20 days). None had any secondary infections and none died. The nutritional data for the two groups are shown in table I. The patients were clearly stunted and malnourished compared with the controls.

Patients and controls were vaccinated with meningococcal group $C$ vaccine (Institut Merieux) and Salmonella typhi vaccine (Burroughs Wellcome), and blood for antibody assay was taken 14 days later.

TABLE I-Nutritional measurements in patients and controls two to four weeks after measles. Values are means $\pm 1 S D$

\begin{tabular}{|c|c|c|c|}
\hline & $\begin{array}{l}\text { Patients } \\
(\mathrm{n}=30)\end{array}$ & $\begin{array}{l}\text { Controls } \\
(\mathrm{n}=25)\end{array}$ & $\mathbf{P}$ \\
\hline $\begin{array}{ll}\text { Weight for age }(\% \text { Harvard standard }) & \ldots \\
\text { Height for age (\% Harvard standard) } & \ldots \\
\text { Arm circumference for age }(\% \text { Harvard } & \cdots\end{array}$ & $\begin{array}{l}60 \pm 11 \\
90 \pm 6^{*}\end{array}$ & $\begin{array}{l}91 \pm 7 \\
97 \pm 3\end{array}$ & $\begin{array}{l}<0.01 \\
<0.01\end{array}$ \\
\hline 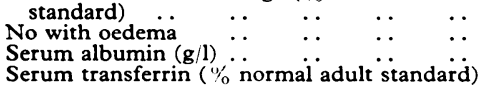 & $\begin{array}{l}75 \pm 8 \\
23 \pm 10 \\
37 \pm 26\end{array}$ & $\begin{array}{l}97 \pm 7 \\
00 \\
30 \pm 7 \\
76 \pm 28\end{array}$ & $\begin{array}{l}<0.01 \\
<0.02 \\
<0.01 \\
<0.01\end{array}$ \\
\hline
\end{tabular}

*Below 3rd percentile of standard for British children. ${ }^{18}$

Haemagglutinating and neutralising antibodies to measles were measured by standard microtitre techniques, Vero cells being used in the neutralisation test. Meningococcal antibodies were measured by microtitre haemagglutination ${ }^{4}$ and antibodies to the $O$ antigen by $S$ typhi by a microtitre method. Serum albumin concentration was measured using bromcresol green ${ }^{5}$ and serum transferrin concentration by the Mancini method, using a monospecific antiserum.

Detection of virus and viral antigens-Cells from nasal secretions ${ }^{6}$ and from lymphocyte culture were stained with $0.1 \%$ acridine orange and examined by fluorescent microscopy for the presence of giant cells. Lymphocytes obtained by defibrination and sedimentation in $3 \%$ dextran were cultured at $1 \times 10^{6} \mathrm{cells} / \mathrm{ml}$ in RPMI medium with $10 \%$ fetal calf serum and phytohaemagglutinin, which was added at an optimal concentration of $5 \mathrm{mg} / \mathrm{l}$, in flat-bottomed microtitre plates. After three days cells were harvested, and some cells and supernatant were stored at $-30^{\circ} \mathrm{C}$ for later viral culture. The rest of the cells were centrifuged and an indirect immunofluorescence test for measles antigen was performed by incubating them with convalescent measles serum and then counter-staining them with an anti-whole immunoglobulin conjugate. In most cases cells from a patient with acute measles, a control patient, and an adult volunteer were cultured simultaneously, 
TABLE II-Number of malnourished children and controls with positive findings in nasal aspirates and stimulated lymphocytes

\begin{tabular}{|c|c|c|c|c|c|c|}
\hline \multirow{2}{*}{ Groups of patients } & \multirow{2}{*}{$\begin{array}{l}\text { Mean ( } \pm \text { SD) No of } \\
\text { days after onset of rash } \\
\text { (and range) }\end{array}$} & \multicolumn{2}{|c|}{ Nasal aspirate } & \multicolumn{3}{|c|}{ Stimulated lymphocytes } \\
\hline & & Giant cells & Virus culture & Giant cells & Immunofluorescence & Virus culture \\
\hline $\begin{array}{l}\text { Malnourished children after measles } \\
\text { Well-nourished children after measles } \\
\text { Well-nourished children with acute measles }\end{array}$ & $\begin{array}{l}13 \pm 7(6-13) \\
12 \pm 4(7-20) \\
1 \cdot 4 \pm 0 \cdot 9(0-4)\end{array}$ & $\begin{array}{r}5 / 17 \\
0 / 10 \\
20 / 20\end{array}$ & $\begin{array}{l}0 / 15 \\
0 / 7 \\
4 / 7\end{array}$ & $\begin{aligned} 7 / 28 \\
0 / 23 \\
18 / 20\end{aligned}$ & $\begin{array}{r}8 / 28 \\
0 / 23 \\
10 / 10\end{array}$ & $\begin{array}{l}0 / 17 \\
0 / 7 \\
5 / 7\end{array}$ \\
\hline
\end{tabular}

and cells were examined independently by two observers. Two types of tissue culture were used: primary human amnion and Vero cells. In each case a monolayer of cells was grown in the walls of flat microtitre plates in Eagle's minimal essential medium supplemented with $10 \%$ fetal calf serum. After two days $100 \mu l$ of the specimen under test was added, and after four hours the medium was replaced and cells incubated in $5 \% \mathrm{CO}_{2}$ in air at $37^{\circ} \mathrm{C}$. Cells were inspected for cytopathic effect at 10,14 , and 18 days. If this was seen cells were harvested and fixed in acetone on slides and then tested for measles and herpes antigen by direct immunofluorescence.

Tests of cellular immunity-A $0 \cdot 1-\mathrm{ml}$ (containing $1 \mathrm{~kg}$ ) sample of a sonicated solution of the strain of Candida used in the migration inhibition test was injected intracutaneously in the forearm and the test read 48 hours later. A microtest was used ${ }^{7}$ for the leucocyte migration test to candida and measles antigen. The candida antigen consisted of heat-killed candida cells at a final concentration of $1 \times 10^{8} /$ $\mathrm{ml}$ (kindly provided by Dr Mackenzie, of the Ross Institute, London). The measles antigen was a haemagglutinating antigen treated with Tween-ether (Behringwerke), and a suitable control was also provided by Behringwerke. The results were expressed as a migration index, which was the ratio of the area of migration of the cells in medium containing antigen to that of cells in medium without antigen.

\section{Results and comment}

\section{PERSISTENCE OF VIRUS}

Evidence of persistence of measles infection six to 13 days after the onset of the rash was found by one or more tests in 12 of the 30 $(40 \%)$ children who were malnourished and debilitated after measles but in none of the 25 well-nourished children who had made an uneventful recovery $\left(\chi^{2}=7 \cdot 1 ; P<0.01\right)$ (table II). Evidence of virus was also found in all of the 20 well-nourished children with acute measles (table II). Three of the nasal aspirate cultures from the malnourished children grew herpes simplex virus; this was not found in any of the controls.

The nutritional status, as judged by height for age, weight for age, or serum albumin concentration; the number of secondary infections, such as pneumonia and stomatitis; and the mortality $(50 \%)$ were no different between malnourished children with persisting virus and malnourished children without persisting virus. The only significant difference was in the severity of the rash: seven of the 12 children with evidence of persistent virus had a severe rash but only three of the other 18 malnourished children did so $\left(\chi^{2}=5 \cdot 6 ; P<0.02\right)$.

Three malnourished children had large amounts of measles antigen in their lymphocytes associated with very low concentrations of haemagglutinating and neutralising antibody. These three patients died.

\section{CELL-MEDIATED IMMUNITY}

Skin test-None of the 22 malnourished patients tested had a positive reaction to candida antigen two weeks after measles. In contrast five out of 22 well-nourished patients had a positive response at two weeks $\left(\chi^{2}=4 \cdot 1 ; \mathrm{P}<0.05\right)$.

Leucocyte migration inhibition tests-The mean migration index to

TABLE III-Mean rise in antibody titre $\left(\log _{2}\right)$ to measles and other antigens in malnourished patients and controls two to four weeks after measles

\begin{tabular}{l|c|c}
\hline & Patients & Controls \\
\cline { 1 - 2 } Measles haemagglutinating antibody & $5 \cdot 1 \pm 2 \cdot 3(\mathrm{n}=29)$ & $5 \cdot 7 \pm 1 \cdot 5(\mathrm{n}=24)$ \\
Measles neutralising antibody & $8 \cdot 6 \pm 2 \cdot 5(\mathrm{n}=15)$ & $9 \cdot 4 \pm 0 \cdot 8(\mathrm{n}=15)$ \\
Meningococcal group C antibody & $2 \cdot 1 \pm 2 \cdot 0(\mathrm{n}=22)$ & $4 \cdot 3 \pm 3 \cdot 2(\mathrm{n}=17)$ \\
Styphi O antibody & $1 \cdot 7 \pm 1 \cdot 8(\mathrm{n}=22)$ & $1 \cdot 6 \pm 1 \cdot 6(\mathrm{n}=23)$ \\
\hline
\end{tabular}

measles antigen was $0 \cdot 78 \pm 0.15$ in 16 malnourished patients and $0.62 \pm 0.12$ in 20 well-nourished controls $(t=3.6 ; \mathrm{P}<0.01)$. There was no difference in the migration index between those malnourished patients with evidence of persisting virus infection and those without. The mean migration index $( \pm 1 S D)$ to candida antigen was $0.96 \pm 0.09$ in 15 malnourished patients compared with $0.87 \pm 0.13$ in 15 wellnourished controls $(t=2.2 ; \mathrm{P}<0.025)$. Four weeks after measles the mean index in the well-nourished children had fallen to $0.75 \pm 0.08$.

\section{HUMORAL IMMUNITY}

Mean levels of haemagglutinating antibody and neutralising antibody to measles in the patients and controls are shown in table III. The responses of malnourished and well-nourished children to vaccination with meningococcal and typhoid vaccines two weeks after measles are also shown. Malnourished patients showed a significantly diminished response to meningococcal vaccine but not to typhoid vaccine $(t=2 \cdot 7$; $\mathrm{P}<0.02)$. The other differences were not statistically significant.

\section{Discussion}

Malnutrition commonly accompanies severe measles ${ }^{1}$ and it is often difficult to unravel the relation between the two. We found that the 30 children whom we studied who were malnourished after measles were stunted as well as being underweight, which indicated that they had been malnourished before they contracted measles. The likely sequence of events in these patients was as follows (see figure): malnutrition impaired their cellular $^{8}$ and humoral immunity, ${ }^{9}$ which resulted in a severe attack of measles with persisting virus in some cases; this severe measles infection made their malnutrition worse and further impaired their immune system, rendering them more susceptible to secondary infection, which was the main cause of death.

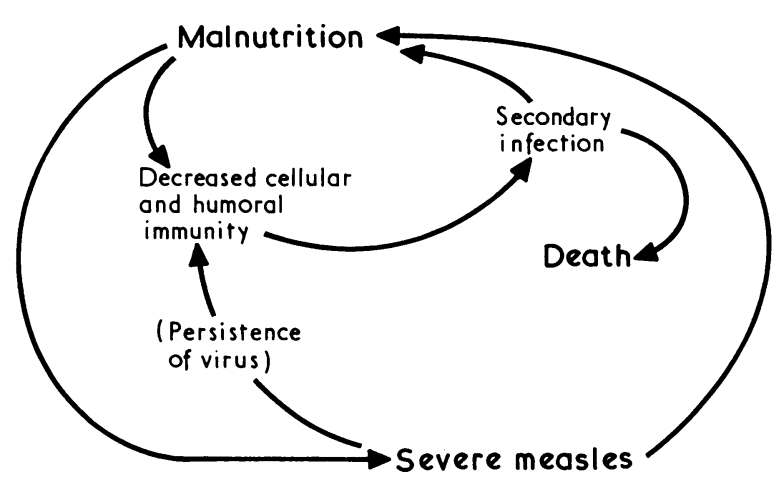

Probable sequence of events in malnourished children with measles.

In acute measles giant cells can be found in nasal secretions ${ }^{10}$ and lymphocytes can be stimulated with phytohaemagglutinin to form giant cells carrying surface measles antigen. ${ }^{11} \mathrm{We}$ used both these investigations to detect persisting virus in the children. The use of acridine orange with fluorescence microscopy made it easier to detect living giant cells than it would have been if we had stained fixed preparations with methylene blue, particularly in nasal secretions, where very few giant cells were present. Evidence of persisting virus was found in $40 \%$ of the 
malnourished patients but in none of the controls. Of the 10 patients with severe skin changes seven had evidence of viral persistence, which agrees with the findings of Scheifele and Forbes, ${ }^{2}$ who found prolonged nasal giant cell excretion after measles in patients who had suffered severe skin change.

Despite the presence of giant cells, we could not culture measles virus from either nasal secretions or blood in any of our malnourished patients two to four weeks after the infection, although we had little difficulty in growing the virus from patients with acute measles. Our results suggest that these malnourished patients are unlikely to be infectious when they come to hospital.

The malnourished children showed severe impairment of cellmediated immunity, which was probably the combined result of the immunosuppressive effects of their malnutrition and their persistent virus infection. Cell-mediated immunity to Candida was severely impaired, and six patients had oral candidiasis. This impaired immunity has also been found in malnourished children in Indonesia ${ }^{12}$ and may result in candida infection in the gut. ${ }^{13}$ The malnourished children also showed significantly less leucocyte inhibition to measles antigen than the controls. Although there is some doubt about whether this test is a specific measure of cell-mediated immunity, ${ }^{14}$ we have found that non-immune cord blood lymphocytes show significantly less inhibition than immune lymphocytes, and we have also been able to reverse the inhibition to immune cells by using puromycin. ${ }^{15}$ Thus we think that this difference between patients and controls probably indicates poorer cell-mediated immunity to measles in the malnourished children.

The malnourished children produced normal amounts of measles antibody, except for three whose lymphocytes were heavily infected with virus and all of whom died. The response to $S$ typhi vaccine, which was mainly a secondary response, was not significantly different from that in the control group. Nevertheless, both groups showed a lower rise in titre than we have obtained in normal children with no recent history of measles. ${ }^{16}$ The response to meningococcal group $\mathrm{C}$ polysaccharide, a primary response, was significantly depressed in the malnourished patients, suggesting that such children may have a poor response to coccal infections. This might make them susceptible to staphylococcal pneumonia, which is a very common cause of death after measles. ${ }^{17}$

Depression of the immune responses, such as we found in these children, is likely to increase the patients' susceptibility to secondary infections, and both viral and bacterial secondary infections were common. Such infections largely accounted for the high mortality among the malnourished children. Herpes virus was grown from the nasal secretions of three of the patients and this may have been disseminated in one child who died. We believe that persistence of measles virus plays an important part in the pathogenesis of malnutrition and debility after measles. The morbidity is mainly due to suppression of the immune response by the virus, which leads to secondary infections, rather than to the direct destructive action of the virus itself. Nevertheless, three of the patients in this study who died had heavy viraemia and low levels of antibody and clearly died from overwhelming measles infection.

We thank Mr J K Mayaki and Mr Ibrahim Dabo for invaluable help with the field work. This work was supported by a grant from MRC, UK.

Requests for reprints should be sent to Dr J Dossetor.

\section{References}

${ }^{1}$ Morley, D, Woodland, M, and Martin, W J, fournal of Hygiene, 1963, 61, 115

2 Scheifele, D W, and Forbes, C E, Pediatrics, 1972, 50, 867.

3 Lancet, 1970, 2, 302.

${ }^{4}$ Artenstein, M S, et al, fournal of Infectious Diseases, 1971, 124, 277.

5 Doumas, B T, Watson, W A, and Biggs, H G, Clinica Chimica Acta, 1971 , 31, 87.

6 Auger, W J, fournal of Pediatrics, 1939, 15, 640.

7 Maini, R N, et al, International Archives of Allergy and Applied Immunology, $1973,45,308$.

8 Smythe, P M, et al, Lancet, 1971, 2, 939.

9 Chandra, R K, Fournal of Pediatrics, 1972, 81, 1194.

10 Tompkins, V, and Macauley, J C, fournal of the American Medical Association, 1955, 157, 711 .

11 Osunkoya, B O, et al, Archiv für Virusforschung, 1974, 44, 323.

12 Gracey, M, et al, American fournal of Clinical Nutrition, 1973, 26, 1170.

${ }^{13}$ Dossetor, J, unpublished.

14 Nordal, H J, et al, Lancet, 1975, 2, 1266.

15 Whittle, H C, unpublished.

${ }^{16}$ Whittle, H C, et al, Archives of Disease in Childhood, 1973, 48, 753.

17 Williams, A O, and Osotimehin, B, Ghana Medical fournal, 1970, 9, 23.

18 Tamner, J M, Whitehouse, R H and Takaishi, M, Archives of Diseases in Childhood, 1966, 41, 454.

\title{
Unnecessary polypharmacy for epilepsy
}

\author{
S D SHORVON, E H REYNOLDS
}

British Medical fournal, 1977, 1, 1635-1637

\section{Summary}

A retrospective survey of 50 adult epileptic outpatients who were taking two anticonvulsant drugs showed that seizure control had improved in the six months after the introduction of the second drug in only $36 \%$. When blood concentrations of the two anticonvulsants were subse-

University Department of Neurology, Institute of Psychiatry, and King's College Hospital, London SE5

S D SHORVON, MA, MRCP, honorary registrar

E H REYNOLDS, MD, MRCP, consultant neurologist quently measured improvement in seizure control was found to be significantly related to the presence of optimum blood concentrations of at least one drug. Much unnecessary polypharmacy in the treatment of epilepsy could be avoided by ensuring an optimum blood concentration of one drug before considering the addition of a second.

\section{Introduction}

Epileptics are commonly treated with more than one anticonvulsant drug. A survey in four European countries found that 11720 patients, randomly selected from inpatient and outpatient populations, were receiving 3.2 drugs per patient, of which $84.3 \%$ were anticonvulsants. ${ }^{1}$ We have been concerned at the extent of this polypharmacy for three reasons. Firstly, 